\title{
The Investigation of Teachers' Metaphoric Perceptions about Professional Development
}

\author{
Nihal Yurtseven ${ }^{1}$ \\ ${ }^{1}$ School of Foreign Languages, Yildiz Technical University, Istanbul, Turkey \\ Correspondence: Nihal Yurtseven, School of Foreign Languages, Yildiz Technical University, Istanbul, Turkey. \\ E-mail: yurtsevennihal@gmail.com
}

Received: December 7, 2016

Accepted: December 28, 2016 Online Published: January 5, 2017

doi:10.5539/jel.v6n2p120

URL: http://dx.doi.org/10.5539/jel.v6n2p120

\begin{abstract}
Professional development is an ongoing process in which teachers review their teaching practices and learn how to respond to their students' needs. To make the professional development process more effective, we need to define the identity of a teacher correctly and clarify the perspective about teachers' professional development. The purpose of this study is to investigate teachers' metaphoric perceptions about professional development. The study was carried out through qualitative research design. The data was collected via an electronic form. The participants were 526 teachers that the researcher contacted through e-mail or social media sites. The data was analyzed through content analysis. The findings of the study indicated that the participants often associated the concept of professional development with an object. In addition, they regarded professional development as a growing and developing entity as well as a demanding occupation that involved change. In this respect, it is important that the teachers are provided with the required resources, budget and time to continue their professional development. Moreover, it is crucial that professional development activities are not limited to seminars and teachers are given the initiative to conduct research about their teaching process.
\end{abstract}

Keywords: teacher, professional development, metaphor, metaphoric perception

\section{Introduction}

Professional development is an ongoing process in which teachers review their teaching practices and learn how to respond to their students' needs (Diaz-Maggioli, 2004). The main objectives of professional development are to increase the diversity of teachers' practices; to support teachers to meet students' needs by providing them feedback about what they do; to contribute to the professional development network in school settings and to improve teaching standards within the educational policies framework (Blanford, 2001).

In an educational institution, failure to take professional development into consideration or to ignore it cause teachers to experience problems related to updating their teaching practices and content knowledge (Yildirim, 2013). Therefore, it is crucial that the teachers receive support for both sustaining their professional development and collaborating with their colleagues (TALIS, 2013; Warren-Little, 2012).

We need to define the identity of a teacher correctly and clarify the perspective about their professional development in order to make progress about achieving the aforementioned goals since a number of negative attitudes related with this perspective cause difficulties to carry out the process properly (Kwo, 2010). One of these negative attitudes is that professional development is a compulsory single-session seminar or a program organized by the administrators. As a matter of fact, such programs that are often planned independently of teachers' needs become an extra burden for them rather than finding solutions to problems in the classrooms. Another negative attitude is that professional development is the process of "correcting teachers". The most obvious underlying reason is the belief that student failure stems from teachers (Diaz-Maggioli, 2004; Jamwal, 2012). In addition to these problems, there are several factors affecting teachers' professional life. For instance, ignoring teachers' needs (Garet, Porter, Desimone, Birman, \& Suk Yoon, 2001), teachers' missing the chance to take part in professional development programs (Birman, Desimone, Porter, \& Garet, 2000), failure to deal with professional development as a systematical whole (Desimone, 2009), limiting it to the seminars and panels and teachers' not having the chance to collaborate with their peers (Darling-Hammond \& McLaughlin, 1995; Ingvarson, Meiers, \& Beavis, 2005) are among these factors. It is vital to review these problems and to solve them in an efficient manner in order to achieve the objectives mentioned above. 
Research in Turkey about teachers' professional development mainly focuses on topics related to the relationship between professional development and classroom practices or students' achievement (Bas, 2013; Ozkan, 2011; Yurtseven, 2016); teachers' pedagogical content knowledge (Ay, 2015; Gencosman, 2015; Sahin, 2016; Yenmez, 2012); factors affecting professional development process (Bayhan, 2011; Iyidogan, 2011; Ozbek, 2014) and the efficiency of professional development programs for teachers (Balta, 2014; Kanadli, 2012; Kocagul, 2013; Mutlu, 2012). Although many research findings support the fact that professional development is critical for teachers, the important thing is how teachers perceive this fact with their own perspectives $($ Onkol, 2011) since an individual's perspective or perception about a phenomenon plays a decisive role in shaping his/her actions. At this point, teachers' perceptions about professional development can make important contributions to the identification of the concept of teachers' professional development as well as resolving potential problems.

One of the tools to be utilized to identify individuals' perspectives about a certain concept is the metaphor. Metaphors, which have been widely used in social sciences recently, are tools that individuals use to explain abstract or complicated phenomena and they make important contributions to communication and expression skills (Aykac \& Celik, 2014). Metaphors are used to express phenomena that are difficult to define, to enrich the language, and to convert thoughts into linguistic actions. In this way, they help individuals to express themselves more easily to share the images in their minds with other people (Lakoff \& Johnson, 2005; Yalcin, Ozoglu, \& Donmez, 2016; Yob, 2003).

There are several studies on metaphors in the literature (Chan, 2013; Fang, 2015; Haynes \& Bulosan, 2012; Izadinia, 2016; Kee, 2007; Latterell \& Wilson, 2016; Meral, Kucuk, \& Gedik, 2016; Thomas \& Beauchamp, 2011; Timor, 2012; Wegner \& Nückles, 2015; Yalcin, Ozoglu, \& Donmez, 2016; Yalmanci, 2013; Yilmaz, Gocen, \& Yilmaz, 2013). For instance, Fang (2015) carried out a study with an aim to examine university students' metaphoric perceptions about learning English. At the end of his study, he concluded that students perceived learning English as a task that was difficult and requiring patience. Yalcin et al. (2016) aimed to reveal the metaphorical perceptions of lecturers about research assistants and gathered data from different faculties of education in Turkey. At the end of the study, they found out that there were both positive and negative perceptions towards research assistants and that they had to struggle with a great many difficulties as well as having to spend their time on various things apart from their own work. Although there were studies about the curriculum, social perception of gender, solving a mathematics problem, education, mentoring and many other topics, there was a paucity of research about teachers' metaphoric perceptions on professional development.

It is critical to examine how teachers perceive the concept of professional development, in order to scrutinize the positive and negative viewpoints and to uncover potential problems. This is because metaphors are efficient tools to be used for examining individuals' perceptions about a concept and they can be utilized to present thoughts and to express the truth and realities (Lakoff \& Johnson, 2003; Yalcin et al., 2016). In this respect, the purpose of this study is to investigate teachers' metaphoric perceptions about professional development. For this purpose, the following research question underpins the study:

- Which concepts and reasons did the teachers and use to express their perceptions about the concept of professional development?

It was assumed that all the participants were teachers, they answered the questions in the data collection tool sincerely, and the tool was valid and reliable.

\section{Method}

\subsection{Research Design}

The qualitative research design was used in this study. Qualitative research is conducted in order to reveal individuals' experiences, perceptions, and perspectives (McMillan \& Schumacher, 2006). In the studies that are carried out by adopting a qualitative design, the researchers try to display the participants' perceptions and the meaning they have attributed to the events are examined in depth and the perspective about the phenomenon in an unbiased manner (Bas \& Akturan, 2013; Creswell, 2015; Yildirim \& Simsek, 2011). In the present study, the qualitative design was used to deeply examine the perceptions and perspectives of the teachers about the concept of professional development and to reveal the differences in their opinions.

\subsection{Data Collection Tools}

An electronic form was used as a data collection tool in the study. The form consisted of two parts. In the first part, demographic information such as the gender of the participants, the educational stage they work at, type of institution, duration of professional experience, level of education and branch are included. In the second part, there is a semi-structured sentence with two parts, which was created to learn the metaphoric perceptions of the 
participants for professional development. The sentence is "Professional development is like........., because........". The participants needed to produce metaphors in the first part while they need to justify the metaphor they produce in the second part. In this way, the researcher tried to determine for what purpose was the metaphor used and whether these metaphors were valid or not. The data collection process started on 04.04.2016 and ended on 28.09.2016.

\subsection{Participants}

The participants of the study were 526 teachers who were reached through social media and e-mail and filled out the form. Of the 526 participants who participated in the study, 58\% $(n=306)$ were female and $42 \%(n=220)$ were male. The demographic information of the participants are given in Table 1.

Table 1. Demographic information

\begin{tabular}{|c|c|c|}
\hline Demographic Information & $n$ & $\%$ \\
\hline \multicolumn{3}{|l|}{ Educational stage they work at } \\
\hline Preschool & 48 & 9 \\
\hline Primary school & 116 & 22 \\
\hline Secondary school & 70 & 13 \\
\hline High school & 134 & 25 \\
\hline University (instructors) & 158 & 30 \\
\hline \multicolumn{3}{|l|}{ Type of institution } \\
\hline State school & 283 & 54 \\
\hline Private school & 243 & 46 \\
\hline \multicolumn{3}{|l|}{ Duration of professional experience } \\
\hline $0-2$ years & 43 & 8 \\
\hline $3-5$ years & 73 & 14 \\
\hline $6-10$ years & 127 & 24 \\
\hline $11-15$ years & 129 & 25 \\
\hline $16-20$ years & 96 & 18 \\
\hline 21 years and more & 58 & 11 \\
\hline \multicolumn{3}{|l|}{ Level of education } \\
\hline Bachelor's degree & 254 & 48 \\
\hline Master's degree & 196 & 37 \\
\hline Doctoral degree & 76 & 15 \\
\hline \multicolumn{3}{|l|}{ Branch } \\
\hline German & 9 & 1.7 \\
\hline Information Technology & 51 & 9.6 \\
\hline Biology & 11 & 0.1 \\
\hline Geography & 7 & 1.3 \\
\hline Religious culture and ethics & 5 & 0.9 \\
\hline Educational sciences & 13 & 2.4 \\
\hline Philosophy & 7 & 1.3 \\
\hline Physics & 7 & 1.3 \\
\hline French & 9 & 1.7 \\
\hline Science & 33 & 6.2 \\
\hline
\end{tabular}




\begin{tabular}{lcc}
\hline English & 132 & 25 \\
Spanish & 5 & 0.9 \\
Mathematics & 87 & 16.5 \\
Preschool & 48 & 9.1 \\
Assessment and evaluation & 5 & 0.9 \\
Counseling & 29 & 5.5 \\
Primary school teaching & 41 & 7.8 \\
History & 5 & 0.9 \\
Turkish & 22 & 4.1 \\
\hline
\end{tabular}

As it can be seen in Table 1, 48 of the participants were from preschools, 116 were from primary schools, 70 were from secondary schools, 134 were from high schools, and 158 were from university instructors. While 283 of the participants worked at state schools, 243 of them worked at private schools. 43 of the participants had $0-2$ years, 73 had 3-5 years, 127 had 6-10 years, 129 had 11-15, 96 had 16-20, and 58 had 21 years or more experience. 254 of the participants had bachelor's degree while 196 of them had master's degree and 76 had doctoral degree. Of the 526 participants, 9 worked in German, 51 in information technology, 11 in biology, 7 in geography, 5 in religion culture and ethics, 13 in educational sciences, 7 in philosophy, 7 in physics, 9 in French, 33 in science, 132 in English, 5 in Spanish, 87 in mathematics, 48 in pre-school, 5 in assessment and evaluation, 29 in counseling, 41 in primary school teaching, and 22 worked in Turkish branch.

\subsection{Data Analysis}

The data were analyzed through content analysis. Content analysis can be defined as to combine data within the framework of similar concepts and themes, to organize them so that the reader can understand and interpret (Yildirim \& Simsek, 2008). The primary objective in qualitative data analysis is to examine the collected data in depth and to create themes and patterns among them (Glesne, 2012). In the present study, the content analysis was conducted in five steps:

1) All responses obtained were listed alphabetically in a separate file.

2) The convenience of the responses that were listed alphabetically was determined and the data that were found to be non-metaphorical were removed from the list. For example, answers such as "Professional development is very important." were not accepted as metaphors. Similarly, the metaphors that lacked an explanation were also removed from the list.

3) The remaining metaphors were listed alphabetically again and grouped under categories by taking their similar and common characteristics into account.

4) The validity and reliability studies were conducted for the obtained metaphors and categories.

5) The frequencies of the obtained metaphors and categories were calculated.

\subsection{Validity and Reliability of the Study}

Lincoln and Guba's (1985) credibility, transferability, dependability and confirmability terms were referred to for the validity and reliability of the present study. In this framework, two different field experts gave their opinion about the scope, process and data collection procedure to ensure the credibility of the study. In the context of transferability, the researcher examined the previous research in as much detail as possible and tried to draw a detailed picture in order that the present study could shed light on future research. In the context of dependability, the consistency of the study was frequently checked as well as including the analyses of two different researchers and calculating the findings through Miles and Huberman's (1994) reliability formula as mentioned below:

\section{Reliability $=($ Number of Agreement $) /($ Total Number of Agreement + Disagreement $)$}

In this respect, the percentage of agreement obtained from the reliability calculation of three different data analyses was .87; which meant that the present study was reliable according to Miles and Huberman (1994) as it was more than $70 \%$. Finally, in the context of confirmability, two field experts confirmed the accuracy of the findings. 


\section{Findings}

In this study, in which the metaphorical perceptions of the teachers for professional development were examined, the participants produced a total of 143 metaphors. As a result of the reviews made, 46 of these metaphors were considered invalid and the total number of valid metaphors dropped to 97 . The 97 metaphors were divided into 11 categories. These categories included professional development as a nutrient; professional development as an object; professional development as an investment instrument; professional development as a growing/evolving entity; professional development as an occupation including change; professional development as part of nature; professional development as a task requiring labor; professional development as a physiological need; professional development as a negative/unnecessary occupation; professional development as an abstract concept and professional development as a challenging task. Information related to these categories and the number of metaphors produced in each category is given in Table 2.

Table 2. The categories reached as a result of the content analysis

\begin{tabular}{lcc}
\hline Categories & Number of metaphors & $\boldsymbol{f}$ \\
\hline Professional development as a nutrient & 5 & 14 \\
Professional development as an object & 21 & 66 \\
Professional development as an investment instrument & 4 & 18 \\
Professional development as a growing/evolving entity & 14 & 92 \\
Professional development as an occupation including change & 9 & 60 \\
Professional development as part of nature & 8 & 32 \\
Professional development as a task requiring labor & 9 & 36 \\
Professional development as a physiological need & 6 & 60 \\
Professional development as a negative/unnecessary occupation & 6 & 24 \\
Professional development as an abstract concept & 7 & 48 \\
Professional development as a challenging task & 8 & 30 \\
Total & 97 & 480 \\
\hline
\end{tabular}

\subsection{Professional Development as a Nutrient}

14 participants produced five metaphors in this category. These metaphors and their frequencies were; ice cream $(f=2)$; bread $(f=6)$; pumpkin dessert $(f=1)$; fruit $(f=3)$ and wine $(f=2)$. Among these, the most frequently repeated metaphor was "bread".

"Professional development is like bread, because it is a necessity and a teacher that does not update herself/himself loses her/his respect for the teaching profession" (p. 72, Female).

\subsection{Professional Development as an Object}

66 participants produced 21 metaphors in this category in total. These metaphors and their frequencies were; computer $(f=7)$; dress $(f=2)$; home $(f=4)$; hybrid seed $(f=1)$; light $(f=5)$; potion $(f=2)$; processor $(f=1)$; pencil $(f=2)$; container $(f=1)$; gate $(f=5)$; ladder $(f=5)$; toy blocks $(f=4)$; matryoshka doll $(f=1)$; automobile $(f=3)$; pyramid $(f=2)$; bottle $(f=2)$; plane $(f=3)$; kite $(f=9)$; grape extract $(f=1)$; fuel $(f=3)$ and puzzle $(f=3)$. Among these, the most frequently repeated metaphors were "computer", "light", "ladder" and "kite".

"Professional development is like a computer, because like a computer, a teacher should also keep up with the times and be aware of the innovations" (p. 211, Male).

"Professional development is like a computer, because a teacher's capacity increases she/he gets the energy. As the knowledge increases, the teacher grows professionally" (p. 82, Female).

"Professional development is like a ladder, because you reach the summit as you step up each step" (p. 227, Female).

"Professional development is like a kite, because you become independent and you rise you grow professionally" (p. 47, Female). 


\subsection{Professional Development as an Investment Instrument}

18 participants produced four metaphors in this category. These metaphors and their frequencies were; gold $(f=6)$; treasure $(f=3)$; moneybox $(f=4)$ and money $(f=5)$. Among these, the most frequently repeated metaphor was "gold".

"Professional development is like gold, because you can shine in every place and time if you improve yourself" (p. 153, Female).

\subsection{Professional Development as a Growing/Evolving Entity}

92 participants produced 14 metaphors in this category in total. These metaphors and their frequencies were; tree $(f=30)$; river $(f=8)$; spike $(f=6)$; baby $(f=12)$; avalanche $(f=2)$; flower $(f=4)$; child $(f=8)$; embryo $(f=2)$; power plant $(f=2)$; evolution $(f=4)$; seedlings $(f=10)$; snowball $(f=2)$, ivy $(f=1)$ and caterpillar turning into a butterfly $(f=1)$. Among these, the most frequently repeated metaphors were "tree", "baby" and "seedlings".

"Professional development is like a tree, because it takes time. It needs water and sunlight. It requires patience. Professional development is also a case that can happen over time. Of course, it depends on whether you spend time developing yourself and nurturing it in the sense of science and experience" (p. 8 , Female).

"Professional development is like a baby, because a newborn baby cannot meet her/his needs and is open to learning. It is constantly interrupted. Throughout her/his life, a teacher learns new things and begins practicing when she/he reaches self-actualization stage in a professional sense. In this process, she/he passes many positive-negative tests. This is why professional development is like a baby. While you do not have any knowledge at the beginning, you learn about yourself in the process and continue to learn through overcoming obstacles" (p. 33, Female).

"Professional development is like seedlings, because the seedlings grow bigger and bigger as they grow. They give more shade and fruit" (p. 241, Male).

\subsection{Professional Development as an Occupation Including Change}

60 participants produced nine metaphors in this category. These metaphors and their frequencies were; training $(f=2)$; dialectics $(f=2)$; marbling art $(f=2)$; life $(f=26)$; media $(f=2)$; changing the shell $(f=2)$; experience $(f=2)$; technology $(f=2)$ and journey $(f=20)$. Among these, the most frequently repeated metaphors were "life" and "journey".

"Professional development is like the life, because we must strive for better with hope in both of them" (p. 332, Female).

"Professional development is like a journey, because it is the whole of the experiences we have at every stop throughout an endless journey" (p. 452, Male).

\subsection{Professional Development as Part of Nature}

32 participants produced eight metaphors in this category. These metaphors and their frequencies were; cloud $(f=1)$; wave $(f=1)$; sea $(f=4)$; rainbow $(f=1)$; sun $(f=8)$; ocean $(f=14)$; wind $(f=1)$ and rain $(f=2)$. Among these, the most frequently repeated metaphors were "ocean" and "sun".

"Professional development is like the ocean, because it is infinite, fascinating, sometimes stagnant, and sometimes exuberant" (p. 130, Female).

"Professional development is like the sun, because it gives light and illuminates everywhere" (p. 479, Male).

\subsection{Professional Development as a Task Requiring Labor}

36 participants produced nine metaphors in this category. These metaphors and their frequencies were; motherhood ( $\mathrm{f}=6)$; driving a car $(\mathrm{f}=6)$; vineyard $(\mathrm{f}=1)$; making honey $(\mathrm{f}=1)$; education $(\mathrm{f}=6)$; doing sports $(\mathrm{f}=5)$; watering the seeds $(\mathrm{f}=1)$; flying $(\mathrm{f}=7)$ and cooking $(\mathrm{f}=3)$. Among these, the most frequently repeated metaphors were "flying", "motherhood" and "driving a car".

"Professional development is like flying, because climbing up takes labor. You develop yourself and follow the people around, you feel free and become open to innovations" (p. 441, Female).

"Professional development is like motherhood, because the more you try and feed your baby, and the more it grows" (p. 202, Male). 
"Professional development is like driving a car, because you learn to drive. However, you need to make sure that you are as cool as a professional taxi driver and know what you are doing when there are events developing outside of you in traffic, you need to do sudden maneuvers, when you are in the middle of a traffic accident or when your tire explodes suddenly. It requires time" (p. 34, Female).

\subsection{Professional Development as a Physiological Need}

60 participants produced six metaphors in this category. These metaphors and their frequencies were; getting hungry ( $\mathrm{f}=4$ ); eating $(\mathrm{f}=5)$; breathing $(\mathrm{f}=12)$; drinking water $(\mathrm{f}=27)$; sleep $(\mathrm{f}=5)$ and vitamin $(\mathrm{f}=7)$. Among these, the most frequently repeated metaphors were "drinking water" and "breathing".

"Professional development is like drinking water, because it is a vital need" (p. 507, Male).

"Professional development is like breathing, because if you do not improve yourself, you are without oxygen and you run out slowly" (p. 247, Female).

\subsection{Professional Development as a Negative/Unnecessary Occupation}

24 participants produced six metaphors in this category. These metaphors and their frequencies were; a thorny path $(f=2)$; a bottomless pit $(f=7)$; a hamster's cage $(f=1)$; a bumpy road $(f=9)$; torture $(f=4)$ and looking for a black cat in a dark room $(f=1)$. Among these, the most frequently repeated metaphors were "a bumpy road" and "a bottomless pit".

"Professional development is like a bumpy road, because it is quite possible to encounter too many problems while trying to achieve this goal. The people who are not supportive of you are high in number. I think that there are many people who do not believe and support professional development in our country" (p. 22, Female).

"Professional development is like a bottomless pit, because no matter how hard you try, you cannot reach a place and the end of the road is dark" (p. 286, Male).

\subsection{Professional Development as an Abstract Concept}

48 participants produced seven metaphors in this category. These metaphors and their frequencies were; ambition $(f=6)$; faith $(f=3)$; self-confidence $(f=4)$; loyalty $(f=6)$; love $(f=10)$; passion $(f=12)$ and fidelity $(f=7)$. Among these, the most frequently repeated metaphors were "passion" and "fidelity".

"Professional development is like passion, because it captures you like passion and helps you achieve information that you never had" (p. 517, Male).

"Professional development is like fidelity, because you hopefully need to make effort to take it to a better place without giving up" (p. 463, Female).

\subsection{Professional Development as a Challenging Task}

30 participants produced eight metaphors in this category. These metaphors and their frequencies were; riding a bicycle $(f=1)$; walking in a desert $(f=3)$; climbing a mountain $(f=6)$; diving $(f=2)$; losing weight $(f=2)$; a marathon race $(f=2)$; a journey of discovery $(f=12)$ and swimming $(f=2)$. Among these, the most frequently repeated metaphors were "a journey of discovery" and "climbing a mountain".

"Professional development is like a journey of discovery, because there are many things to see and learn along the way and to experience by living" (p. 5, Female).

"Professional development is like climbing a mountain, because the more you rise, the more things you add to your knowledge. You start with less, and you gradually add to your knowledge" (p. 172, Male).

To sum up, it turned out that the participants associated the concept of professional development with an object; viewed it as a growing and evolving entity, an occupation including change and a task requiring labor.

\section{Conclusion, Discussion, and Recommendations}

The purpose of this study is to investigate teachers' metaphoric perceptions about professional development. Metaphors are tools that help people express their perceptions and thoughts more clearly and they make important contributions to people to have an active thinking process while they are generating metaphors (Kesen, 2013; Littlewood, 2006). In this framework, when the metaphors obtained were content analyzed, it was found out that 11 categories emerged after the analyses. Among these categories, the category in which the participants produced metaphors the most was professional development as an object. In this category, the most frequently repeated object was the computer. When the participants' explanations were examined, it was quite striking to notice that they had the opinion that teachers should be updated. In the past, the distribution of knowledge and 
the disciplinary changes were not as rapid as they are today, and teachers were not expected to update their knowledge as they are expected these days (McDiarmid \& Clevenger-Bright, 2008). However, many developments such as the shift to the Digital Age (Bush, Driskell, Niess, Pugalee, Rakes, \& Ronau, 2015), the emphasis on learning differences (Tomlinson \& McTighe, 2006), and the change in expectations from teachers (Johnson \& Kardos, 2008) have forced teachers to participate in a variety of activities to update and expand their knowledge (Gorinski, 2008) in recent years. At this point, the findings obtained reflect the current paradigm on sustaining the professional development of teachers. For this very reason, it is a stubborn fact that teachers are supposed to keep up with the trends, contemporary approaches to teaching, and update their knowledge.

The two categories in which the participants produced the most metaphors were professional development as a growing/evolving entity and professional development as an occupation including change. Teachers' collaborating with colleagues, working on increasing student success, planning future teaching by keeping an eye on their teaching practices, and many other elements are parts of professional development (Davis \& Moely, 2008). In addition, the most effective way to see if a skill has been gained in the professional development process is applying the knowledge gained in real life (Eksi, 2012). This is also important for continuing teachers professional development and continuing school development studies (Seferoglu, 2000). In this context, the fact that teachers need to take an active role during their professional life and the view that they gain in the process of monitoring their own experiences may have caused professional development to be perceived as a growing and developing entity.

Another category where metaphors were produced for the concept of professional development was professional development as a task requiring labor. In this category, in which metaphors such as motherhood, driving a car and education were frequently repeated, it was emphasized that professional development required a great deal of time and effort. Teaching, by its nature, is a profession that is complex and requires labor, and the success of a teacher in her/his profession has a direct impact on the quality of learning (Hung, Oi, Chee, \& Man, 2008). In this vein, teachers need to develop multifaceted thinking skills, internalize the values of the institution they are affiliated with, and take strategic steps in co-operation in the teaching profession so that they can learn how to teach (Calderhead \& Shorrock, 2005). Moreover, it is an obvious fact that a teacher should have the qualities such as dedication (Al-Hinai, 2008), loyalty to the profession (Townsend \& Bates, 2008), and content knowledge (Stronge, Tucker, \& Hindman, 2004) and so forth.

Some of the categories reached at the end indicate that participants perceived professional development as a physiological need and part of the nature. At this point, the frequently repeated metaphors such as drinking water and breathing emphasize the fact that professional development is an indispensable need. Teachers continue their development when they have the opportunity to acquire necessary knowledge and skills (Stronge et al., 2004). It is possible that they will feel burnout (Hakanen, Bakker, \& Schaufeli, 2006), professional deformation (Hanesová, 2016) and loneliness (Ferrier-Kerr, 2012) if they face the opposite situation and do not receive enough support for professional development. Therefore, it is very important for teachers to receive the necessary support in their professional development processes, which they perceive as important as breathing or water and need to continue the learning process as a teacher.

Apart from the picture depicted above, the two noteworthy categories that emerged from the metaphors were professional development as a negative/unnecessary occupation and professional development as a challenging task. The metaphors produced in these categories indicated that professional development was not a refreshing instructive task for the teachers, but rather it was a waste of time, torture, and a complicated process. The underlying reason for this view may be that the participants did not receive enough support to improve themselves. All around the world, significant amounts of budget are allocated to in-service seminars every year. However, many of these seminars are not kinds of seminars that address individual differences, improve teachers' intellectual sense, or describe how they can improve their teaching practice (Ball \& Cohen, 1999; Diaz-Maggioli, 2004; Kyriakides, Creemers, \& Antoniou, 2009). Besides, test-oriented education systems and student achievement expectations that are common in many parts of the world are adding to the expectations from teachers (Borko, 2004). Unfortunately, after completing the undergraduate studies, many teachers have difficulty in reaching the resources for the support and guidance that are necessary to meet the demands directed at them (Hardy, 2012; Yildirim, 2013). These reasons and teachers' experiences may have caused them to feel as if they were walking on a thorny path and to experience the sense of helplessness.

In conclusion, professional development is a phenomenon that teachers consider as an important and indispensable part of their profession. In the light of these findings and conclusions, teachers need to be supported by allocating the necessary resources, budget and time. Moreover, it is important that professional 
development activities are not only limited to seminars and teachers should be given the knowledge and initiative to conduct their own research about their instructional process. In this vein, professional development activities should be made more efficient in schools and teachers should benefit from workshops and tools such as professional learning communities and peer assessment. In future research, professional development can be addressed in more specific dimensions. In addition, future research can examine why professional development is perceived as an unnecessary occupation within the framework of different research designs.

\section{References}

Al-Hinai, A. M. (2008). The interplay between culture, teacher professioanlism and teachers' Professional development at times of change. In T. Townsend, \& R. Bates (Eds.), Handbook of teacher education: Globalization, standards and professionalism in times of change (pp. 41-52). Netherlands: Springer.

Ay, Y. (2015). Evaluation of teachers' technological pedagogical content knowledge (TPACK) within the framework of practical model (Doctoral Dissertation). Eskisehir Osmangazi University, Turkey.

Aykac, N., \& Celik, O. (2014). Comparison of methaphoric perception of teachers and pre-service teachers about curriculum. Education and Science, 39(173), 328-340.

Ball, D. L., \& Cohen, D. K. (1999). Developing practice, developing practitioners: Toward a practice-based theory of Professional education. In L. Darling-Hammond, \& G. Sykes (Eds.), Teaching as the learning profession (pp. 3-31). San Francisco, CA: Jossey-Bass.

Balta, N. (2014). The effect of a professional development program on physics teachers' knowledge and their students' achievement in modern physics unit (Doctoral Dissertation). Middle East Technical University, Turkey.

Bas, S. (2013). An investigation of teachers' noticing of students' mathematical thinking in the context of a professional development program (Doctoral Dissertation). Middle East Technical University, Turkey.

Bas, T., \& Akturan, U. (2013). Nitel arastirma yontemleri: Nvivo ile nitel veri analizi, ornekleme, analiz, yorum. Ankara: Seckin Yayincilik.

Bayhan, G. (2011). The investigate of teachers' professionalism (Doctoral dissertation). Marmara University, Turkey.

Birman, B. F., Desimone, L., Porter, A. C., \& Garet, M. S. (2000). Designing Professional development that works. Educational Leadership, 28-33.

Blandford, S. (2001). Professional development in schools. Early professional development for teachers (F. Banks, \& S. Mayes, Eds.). England: David Fulton Publishers Ltd.

Borko, H. (2004). Professional development and teacher learning: Mapping the terrain. Educational Researcher, 33(8), 3-15. https://dx.doi.org/10.3102/0013189X033008003

Bush, S. B., Driskell, S. O., Niess, M. L., Pugalee, D., Rakes, C. R., \& Ronau, R. N. (2015). Impact of digital Technologies in Mathematics pre-service teacher preparation over four decades. In M. L. Niess, \& H. Gillow-Wiles (Eds.), Handbook of research on teacher education in the digital age (pp. 1-27). USA: Advances in Higher Education and Professional Development (AHEPD) Series. https://dx.doi.org/10.4018/978-1-4666-8403-4.ch001

Calderhead, J., \& Shorrock, S. B. (2005). Understanding teacher education: Case studies in the Professional development of beginning teachers. USA: The Falmer Press.

Chan, Z. C. Y. (2013). Adolescents' views on families as metaphors in Hong Kong: Implications for pre-counselling assessment. Children $\quad \& \quad$ Society, 27(2), 104-115. https://dx.doi.org/10.1111/j.1099-0860.2011.00390.x

Creswell, J. W. (2012). Educational research: Planning, conducting, and evaluating quantitative and qualitative research. ABD: Pearson Education, Inc.

Darling-Hammond, L., \& McLaughlin, M. W. (1995). Policies that support Professional development in an era of reform. The Phi Delta Kappan, 76(8), 597-604.

Davis, T. C., \& Moely, B. (2008). Preparing pre-service teachers and meeting the diversity challenge through structured service-learning and field experiences in urban schools. In T. Townsend, \& R. Bates (Eds.), Handbook of teacher education: Globalization, standards and professionalism in times of change (pp. 283-300). Netherlands: Springer. 
Desimone, L. M. (2009). Improving impact studies of teachers' professional development: Toward better conceptualizations and measures. Educational Researcher, 38(3), 181-199. http://dx.doi.org/10.3102/0013189X08331140

Diaz-Maggioli, G. (2004). Teacher-centered professional development. ABD: Association for Supervision and Curriculum Development.

Eksi, G. (2012). Implementing an observation and feedback form for more effective feedback in microteaching. Education and Science, 37(164), 267-282.

Fang, S. (2015). College EFL Learners' Metaphorical Perceptions of English Learning. The Journal of Asia Tefl, 12(3), 61-79.

Ferrier-Kerr, J. (2012). Moving into the profession. In C. McGee, \& D. Fraser (Eds.), The professional practice of teaching (pp. 291-307). New Zealand: Cengage Learning.

Garet, M. S., Porter, A. C., Desimone, L., Birman, B. F., \& Suk Yoon, K. (2001). What makes professional development effective? Results from a national sample of teachers. American Education Research Journal, 38(4), 915-945. https://dx.doi.org/10.3102/00028312038004915

Gencosman, T. (2015). Investigation of science teachers' technological pedagogical content knowledge according to activity theory (Doctoral dissertation). Gazi University, Turkey.

Glesne, C. (2012). Nitel arastirmaya giris [Becoming qualitative researchers] (A. Ersoy, \& P. Yalcinoglu, Trans.). Ankara: Ani Publishing.

Gorinski, R. (2008). Building leadership capability through Professional development: A New Zealand case study analysis. In T. Townsend, \& R. Bates (Eds.), Handbook of teacher education: Globalization, standards and professionalism in times of change (pp. 465-478). Netherlands: Springer.

Hakanen, J., Bakker, A. B., \& Schaufeli, W. B. (2006). Burnout and work engagement among teachers. The Journal of School Psychology, 43, 495-513. https://dx.doi.org/10.1016/j.jsp.2005.11.001

Hanesová, D. (2016). Teachers under the microscope: A review of research on teachers in a post-communist region. USA: Author House.

Hardy, I. (2012). The politics of teacher Professional development: Policy, research and practice. New York: Routledge.

Haynes, C., \& Bulosan, M. (2012). My world is not my doctoral program ... Or is it? Female students' perceptions of well-being. International Journal of Doctoral Studies, 7(1), 1-17.

Hung, C. M., Oi, A. K., Chee, P. K., \& Main C. L. (2008). Defining the meaning of teacher success in Hong Kong. In T. Townsend, \& R. Bates (Eds.), Handbook of teacher education: Globalization, standards and professionalism in times of change (pp. 415-432). Netherlands: Springer.

Ingvarson, L., Meiers, M., \& Beavis, A. (2005). Factors affecting the impact of professional development programs on teachers' knowledge, practice, student outcomes \& efficacy. Educational Policy Analysis Archives, 13(10), 1-26. https://dx.doi.org/10.14507/epaa.v13n10.2005

Iyidogan, F. (2011). Personal factors affecting experienced English teachers' decisions whether or not to engage in professional development activities (Master's Thesis). Bilkent University, Turkey.

Izadinia, M. (2016). Student teachers' and mentor teachers' perceptions and expectations of a mentoring relationship: Do they match or clash? Professional Development in Education, 42(3), 387-402. https://dx.doi.org/10.1080/19415257.2014.994136

Jamwal, B. S. (2012). Teacher education: Issues and their remedies. International Journal of Educational Planning \& Administration, 2(2), 85-90.

Johnson, S. M., \& Kardos, S. M. (2008). The next generation of teachers: Who enters, who stays, and why. In M. Cochran-Smith, S. Feiman-Nemser, D. J. McIntyre, \& K. E. Demers (Eds.), Handbook of research on teacher education (pp. 445-467). New York: Routledge.

Kanadli, S. (2012). Investigating the effectiveness of a professional development programme designed for teachers (Doctoral Dissertation). Gaziantep University, Turkey. 
Kee, K. F. (2007, November). Blackboard implementation: Metaphoric perceptions and technical descriptions of a cyber infrastructure. Paper to be presented at the meeting of the National Communication Association Conference, Chicago, IL.

Kesen, A. (2013). What lies beneath teacher beliefs? A study on metaphoric perceptions. International Journal of Human Science, 10(1), 1491-1502.

Kocagul, M. (2013). The effect of inquiry based professional development activities on elementary science and technology teachers science process skills and self-efficacy and inquiry based teaching beliefs (Master's Thesis). Dokuz Eylul University, Turkey.

Kwo, O. (2010). Teachers as learners: Critical discourse on challenges and opportunities. China: Springer Comparative Education Research Centre, The University of Hong Kong. https://dx.doi.org/10.1007/978-90-481-9676-0

Kyriakides, L., Creemers, B. P. M., \& Antoniou, P. (2009). Teacher behaviour and student outcomes: Suggestions for research on teacher training and Professional development. Teaching and Teacher Education, 25, 12-23. https://dx.doi.org/10.1016/j.tate.2008.06.001

Lacoff, G., \& Johnson, M. (2003). Metaphors we live by. USA: University of Chicago Press. https://dx.doi.org/10.7208/chicago/9780226470993.001.0001

Lakoff, G., \& Johnson, M. (2005). Metaphors we live by. USA: The University of Chicago Press.

Latterell, C. M., \& Wilson, J. L. (2016). Math is like a lion hunting a sleeping gazelle: Preservice elementary teachers' metaphors of mathematics. European Journal of Science and Mathematics Education, 4(3), 283-292.

Lincoln, Y. S., \& Guba, E. G. (1985). Naturalistic inquiry. ABD: Sage Publications.

Littlewood, W. (2006). Foreign and Second Language Learning (20th ed.). United Kingdom: Cambridge University Press.

Littlewood, W. (2012). Learners' metaphors stimulate thinking and discussion. Modern English Teacher, 21, 12-16.

McDiarmid, G. W., \& Clevenger-Bright, M. (2008). Rethinking teacher capacity. In M. Cochran-Smith, S. Feiman-Nemser, D. J. McIntyre, \& K. E. Demers (Eds.), Handbook of research on teacher education (pp. 134-156). New York: Routledge.

McMillan, J. H., \& Schumacher, S. (2006). Research in education: Evidence-based Inquiry. USA: Pearson Education, Inc.

Meral, E., Kucuk, B., \& Gedik, F. (2016). Sosyal bilgiler ogretmen adaylarinin cevre kavramina iliskin metaforik algilari [Metaphoric comprehension of training teachers of social studies as regards the concept of environment]. Kastamonu Journal of Education, 24(1), 65-78.

Miles, M. B., \& Huberman, A. M. (1994). Qualitative data analysis: An expanded sourcebook. ABD: Sage.

Mutlu, N. (2012). The design and development of an online professional development material for science and technology teachers on assessment and evaluation (Doctoral Dissertation). Middle East Technical University, Turkey.

Onkol, P. E. (2011). Perceptions of professional development at Bilkent university faculty academic English program (Doctoral Dissertation). Middle East Technical University, Turkey.

Ozkan, O. (2011). The long-term effects of action research as a professional development strategy (Master's Thesis). Bilkent University, Turkey.

Sahin, O. (2016). An examination of development of pedagogical content konowledge of prospective middle school mathematics teachers on algebra (Doctoral Dissertation). Ataturk University, Turkey.

Seferoglu, S. S. (2000). Deneyimli ogretmenlerin mesleki gelisimdeki roller [The roles of experienced teachers in the professional development]. Education and Science, 25(118), 9-17.

Stronge, J. H., Tucker, P. D., \& Hindman, J. L. (2004). Handbook for qualities of effective teachers. USA: Association for Suprevision and Curriculum Development. 
TALIS (Teaching and Learning International Survey). (2013). Results: An International Perspective on Teaching Learning. Retrieved from http://www.istruzione.it/allegati/2014/OCSE_TALIS_Rapporto_Internazionale_EN.pdf

Thomas, L., \& Beauchamp, C. (2011). Understanding new teachers' professional identities through metaphor. Teaching and Teacher Education, 27, 762-769. https://dx.doi.org/10.1016/j.tate.2010.12.007

Timor, T. (2012). Student-teachers' metaphorical perceptions of dyslexia and foreign language disabilities. Electronic Journal of Inclusive Education, 2(10), 1-16.

Tomlinson, C. A., \& McTighe, J. (2006). Integrating differentiated instruction and understanding by design. ABD: Association for Supervision and Curriculum Development.

Townsend, T., \& Bates, R. (2008). Teacher education in the new millennium. In T. Townsend, \& R. Bates (Eds.), Handbook of teacher education: Globalization, standards and professionalism in times of change (pp. 3-22). Netherlands: Springer.

Warren-Little, J. (2012). Professional community and professional development in the learning-centered school. In M. Kooy, \& K. van Veen (Eds.), Teacher learning that matters (pp. 22-43). ABD: Routledge.

Wegner, E., \& Nückles, M. (2015). Knowledge acquisition or participation in communities of practice? Academics' metaphors of teaching and learning at the university. Studies in Higher Education, 40(4), 624-643. https://dx.doi.org/10.1080/03075079.2013.842213

Yalcin, M., Ozoglu, E. A., \& Donmez, A. (2016). Metaphoric perceptions of academic staff about the concept of research assistant. Education and Science, 41(185), 19-32.

Yalmanci, S. G., \& Aydin, S. (2013). Ogretmen adaylarinin biyoloji kavramina yonelik metaforik algilari. Mustafa Kemal University Social Sciences Institute Journal, 10(21), 208-223.

Yenmez, A. A. (2012). An investigation of in-service secondary mathematics teachers' evolving knowledge through professional development activities based on modeling perspective (Doctoral Dissertation). Middle East Technical University, Turkey.

Yildirim, A. (2013). Teacher education research in Turkey: Trends, issues and priority areas. Education and Science, 38(169), 175-191.

Yildirim, A., \& Simsek, H. (2011). Sosyal bilimlerde nitel arastirma yontemleri [Qualitative research methods in social sciences]. Ankara: Seckin Publishing.

Yilmaz, F., Gocen, S., \& Yilmaz, F. (2013). Ogretmen adaylarinin ogretmen kavramina 1liskin algilari: Bir metaforik calisma [Pre-service Teachers' Perceptions of the Concept of Teacher]. Mersin University Faculty of Education Journal, 9(1), 151-164.

Yob, I. M. (2003). Thinking constructively with metaphors. Studies in Philosophy and Education, 22, 127-138. https://dx.doi.org/10.1023/A:1022289113443

Yurtseven, N. (2016). The investigation of the reflections of action research based UbD implementations on teachers and students in EFL teaching (Doctoral Dissertation). Yildiz Technical University, Turkey.

\section{Copyrights}

Copyright for this article is retained by the author(s), with first publication rights granted to the journal.

This is an open-access article distributed under the terms and conditions of the Creative Commons Attribution license (http://creativecommons.org/licenses/by/4.0/). 